\title{
Impact of Bureaucratic Simplification on Policy Analyst Functional Positions in Indonesia
}

\author{
Istyadi Insani ${ }^{1}$, Hardi Warsono ${ }^{2}$, Kismartini ${ }^{3}$, Retno Sunu Astuti ${ }^{4}$ \\ $\left\{\right.$ hardie_wsn@yahoo.com ${ }^{2}$ \} \\ Universitas Diponegoro, Indonesia ${ }^{1,2,3,4}$
}

\begin{abstract}
President Joko Widodo's policy in the second term of his administration was to simplify the bureaucracy into 2 levels. This problem occurs because of the rapid change in the policy analyst's functional position which is not accompanied by the current HR management system. This condition has an impact on the performance of policy analysts and organizations. This study aims to analyse the implementation of the policy of transferring administrator positions to functional positions of policy analysts in the era of bureaucratic simplification. The research method used a qualitative descriptive approach. Information is determined with certainty from data sources from relevant Government Agencies, Policy Analysts, and Management Professional Organizations. Data collection was done through literature study. Data analysis techniques with data reduction, presentation and data collection. The data validity used source/data triangulation techniques. The theory uses human resources management system theory. The results showed that the management of functional positions in government agencies was influenced by organizational, resource, development, reward management and employee relations factors. Recommendations are in the form of a functional management model of policy analysts in government agencies in the era of simplification of the bureaucracy.
\end{abstract}

Keywords: Simplification of Bureaucracy, Fonctionnel Position, Policy Analyse, Human Resources Management System

\section{Introduction}

President Joko Widodo's inauguration speech at the MPR RI plenary session in the context of the inauguration of the elected president and vice president for the 2019-2024 government periods in Jakarta on October 20, 2019, became the starting point for the implementation of bureaucratic simplification in Indonesia.

In his speech, President Joko Widodo stated that the simplification of the bureaucracy to 2 (two) levels, namely by transferring structural positions (administrative positions) to functional positions based on expertise and competence. This is based on the composition of the existing state civil apparatus in 2019 which includes $10.26 \%$ or 440,029 people out of $4,286,918$ people consisting of administrative structural officials.

President Joko Widodo's speech was then followed up by Tjahjo Kumolo as Minister of State Apparatus Empowerment and Bureaucratic Reform (Men PANRB) as the Minister who held government affairs in the field of state apparatus by stipulating Regulation of the Minister of State Apparatus Empowerment and Bureaucratic Reform number 28 of 2019 concerning Equalization of Administrative Positions. In a functional position (Permen PANRB Position 
Adjustment) on December 6 2019. One of the contents of this Permen PANRB Position Adjustment in Article 1 point 16 states:

"Equalization of Administrative Positions into Functional Positions, hereinafter referred to as Position Equalization, is the Appointment of Administrative

Officials to Functional Positions through Adjustment/In passing to equivalent functional positions".

This Ministerial Regulation is a legal affirmation of the Men PANRB Circular Letter Number 384, 390 and 391 of 2020 concerning Strategic and Concrete Steps to Simplify Bureaucracy addressed to the Ministers of the Advanced Indonesian Cabinet, Governors and Regents/Mayors throughout Indonesia issued on November 13, 2019. The Men PANRB stated:

"The simplification of the bureaucracy is intended to create a more dynamic, agile, and professional bureaucracy in an effort to increase effectiveness and efficiency to support the performance of government services to the public. This is followed by efforts to increase the competence of State Civil Service Employees".

The SE Men PANRB contains strategic and concrete steps that must be taken by all leaders of Ministries, Institutions whose leaders are at the same level as Ministers, NonMinisterial Government Institutions, Secretariat of State Institutions, Secretariat of NonStructural Institutions, Public Broadcasting Institutions, Provincial Governments, and Regency/City Governments to immediately implement strategic and concrete steps of transfer starting from identification, mapping, alignment of needs, socialization, carrying out the transformation process, and transferring administrative positions into functional positions.

Furthermore, in the development of the implementation of bureaucratic simplification policies in the form of transferring administrator positions to functional positions, it can be seen in the following table

Table 1. Number of Administrative Positions transferred to Functional Positions as of August 2020

\begin{tabular}{|c|c|c|c|c|c|c|}
\hline \multirow[t]{2}{*}{ No. } & \multicolumn{2}{|c|}{ Administration Position } & \multicolumn{3}{|c|}{$\begin{array}{l}\text { Positions that change to Functional } \\
\text { Positions }\end{array}$} & \multirow[t]{2}{*}{ Information } \\
\hline & $\begin{array}{l}\text { Type of } \\
\text { Position }\end{array}$ & $\begin{array}{l}\text { Number of } \\
\text { Employees }\end{array}$ & Position Level & $\begin{array}{l}\text { Number of } \\
\text { Employees }\end{array}$ & $\%$ & \\
\hline 1. & Administrator & 98.658 & Associate expert & 2.889 & 2,93 & \multirow{4}{*}{$\begin{array}{l}\text { Transfers are } \\
\text { prioritized for } \\
33 \text { ministries/ } \\
\text { agencies }\end{array}$} \\
\hline 2. & Supervisor & 327.058 & Young expert & 8.276 & 2,53 & \\
\hline 3. & Executor & 414.313 & First expert & 2.030 & 0,49 & \\
\hline \multicolumn{2}{|c|}{ Total number } & 440.29 & Total number & 13.195 & 0,29 & \\
\hline
\end{tabular}

Until now, the management of the policy analyst functional position, namely since the enactment of the PANRB Ministerial Regulation and its implementing regulations regarding the management of policy analysts, there has not been an ideal management. If it is related to the concept of civil servant human resource management (PNS Management) which is part of ASN Management, the following can be identified:

First, there is a change in the position of a policy analyst functional position with the promulgation of Government Regulation Number 17 of 2020 concerning Amendment to Government Regulation Number 11 of 2017 concerning Management of Civil Servants. This condition affects the preparation and determination of needs and their procurement. 
Second, the rank and position for the policy analyst functional position are still not determined considering that the applicable rank provisions are still waiting for the PP regarding Salary and Allowances to be stipulated.

Third, career patterns and career development for policy analysts' functional positions still require implementing regulations for the Permen PANRB regarding functional positions for policy analysts, especially in policy placement, certification and competency tests at the time of transfer of positions.

Fourth, promotions and transfers for policy analyst functional positions still require clarity given that the position of policy analyst functional positions is related to other functional professions that are in the same position and have a cross section of duties and functions.

Fifth, the performance appraisal for policy analyst functional positions still uses the SKP assessment pattern with the old provisions based on Government Implementing Regulation Number 46 of 2011 concerning Performance Assessment of Civil Servants.

Sixth, the payroll and allowances and awards received by policy analyst functional positions are lower than those of structural equivalent positions before the transfer of positions.

Seven, the provisions regarding discipline, dismissal, pension security and old age security as well as protection for functional positions of policy analysts are still the same as those stipulated before the transfer of positions policy.

Based on the description above and associated with the concept of public management as a grand theory, the concept of human resource management as a middle theory and human resources management system as an empirical theory will be discussed can be formulated as follows: there is no position and division of authority between a policy analyst functional position and other functional positions in the same office and having a slice of duties and functions, recruitment is constrained by the requirements and competency standards of the position at the time of the transfer, there is no career clarity for a policy analyst functional position after a change from an administrative position to a policy analyst functional position and a decrease in the value of remuneration received after switching to a policy analyst functional position. This condition has an impact on the performance of the policy analyst functional position. Thus, the unplanned transfer of an administrative position to a policy analyst functional position has an impact on the management of policy analyst functional positions at government agencies in Indonesia.

\section{Literature Review}

\subsection{Bureaucratic Simplification}

The policy of bureaucratic simplification is not a simple matter, considering that what will be changed is an order that has long been part of the work system of the bureaucracy in Indonesia. Many regulations must be changed and re-harmonized. According to Rovik (in Storkersen, 2020) the deregulation and downsizing of the organizational structure that was carried out actually led to a rebureaucratization of organizational procedures itself. Therefore, it is necessary to have proper documentation and auditing so that every step taken can be read and seen for patterns which then determine what procedures need to be trimmed. 
Bureaucratic simplification is actually not new to Indonesia. During the SBY administration, this has been done under the name of debureaucratization of state administration, but failed. The step taken 10 years ago was a process called organ restructuring and ministerial nomenclature for all levels of echelon of positions. At that time, the Ministry of State Apparatus Empowerment gave signs that the intended restructuring was in the form of streamlining the organizational structure of the ministry, as well as changing the nomenclature according to the new duties and functions. At that time, the term poor structure but rich in function had begun to be socialized. However, instead of downsizing, the restructuring momentum was used to add to the organizational structure. There was an addition of Echelon 1 followed by echelon 2 and subsequent echelons.

Changes in the Indonesian administration system have occurred during the political reforms in 1998 which impacted on public administration. Bureaucratic reform is considered a major change in paradigm and governance which in turn will lead to changes in institutions or organizations, management, human resources, services, accountability and legislation, as well as mindsets. This reform is aimed at realizing good governance or good governance as part of the people's demands but also to respond to world developments in the era of globalization. Even though there are strong demands from society and global change, bureaucratic reform has encountered various obstacles, one of which is a bureaucratic disease called bureusis and called bureunomia by Warsito in [1]. This disease affects the degree of government policy level or the time of formulation compared to the technical operational implementation of government alone.

According to Pasolong [1] bureaunomia is a disease that implants the virus in the government bureaucracy by providing a portion of people who come from parties who have no background knowledge in the bureaucratic field or give bureaucrats privilege who want to be affiliated with the party which will cause inefficiency so that debureaucratization is necessary. If you look at the various cases that exist in the international world, it is necessary to have a strong commitment and national leadership to create success in bureaucratic reform. Various countries carrying out state administrative reforms use the following strategies: (1) revitalizing the position of institutional roles and functions for institutions that are vital to the reform movement; and, (2) restructuring the state administration system in terms of structure, processes, human resources and state-society relations. According to Damanhuri and Jawandi [1], issues and agendas related to bureaucratic reform are modernization of personnel management, streamlining of structures, engineering of government administration processes, performance-based budgeting and participatory planning processes, and new relationships between government and society in development. and governance. Thoha [2] states that the problem in Indonesia is still adopting a system from colonial heritage which is based on law and adjusted to colonial interests in Indonesia so that structures, norms, values, and regulations are still oriented towards fulfilling the interests of the authorities compared to fulfilling citizens' civil rights.

Niskanen [3] argues that in maximizing bureaucratic budgets, reducing costs in providing public services at a certain level will encounter obstacles because savings alone can lead to large budget cuts and also staff reductions. Even with such consequences, it is not surprising that officials who have guaranteed employment for life (state civil servants) will oppose the increase in efficiency. In addition, the existence of information asymmetry between public bodies who know more about the cost function than parliamentarians makes them not want to lose control through this leeway. Another argument is the fear of greater transparency in the performance of officials or apparatus of the agency. 
Asatryan et al. [3] concluded that the inefficient public sector is one of the major obstacles to efforts to recover the country's economy. This has led to a desire for a better understanding of the constraints of administrative reform. Even after research, the crisis did not immediately provide the stage for reforms, but large structural budget cuts could actually increase efficiency in the bureaucracy.

\subsection{Transfer of Structural Positions to Functional Positions}

Etymologically, the word position comes from the basic word "jabatan" (job), which according to the Big Indonesian Dictionary is defined as "a job (task) in government or an organization with regard to rank and position". Meanwhile, according to Logeman [4] in his book translated by Makkatutu and Pangkerego, positions are: "The work environment is durable and is bounded, and is provided to be occupied by office holders who are appointed and provided to be represented by them as individuals. Logeman [4] shows the importance of the relationship between the state as an organization with filling positions, therefore his theory is called the Position Theory.

A structural position is a position that shows the duties, responsibilities, authority and rights of a civil servant in the framework of leading a state organizational unit while a functional position is a position that shows the duties, responsibilities, authority and rights of an ASN person in an organization which in carrying out its duties is based on expertise and/or certain skills and are independent.

Functional positions are essentially technical positions that are not listed in the organizational structure, but are indispensable for the main tasks in government organizations. Civil Servant functional positions consist of functional positions with expertise and skills functional positions. The functional position of expertise is a position which shows the task which is based on knowledge, methodology and technical analysis based on the relevant scientific discipline and/or based on certification which is equivalent to expertise and is determined based on certain accreditation. Meanwhile, a functional skill position is a position that indicates a task that uses certain work procedures and techniques and is based on the handling authority based on a specified certification.

According to Widjaja, the principle of placement is the right man on the right place (placing the right person in the right place). To be able to implement this principle well, there are two things that need to be considered, namely: 1) There is a good job analysis. An analysis that describes the scope and characteristics of the tasks carried out by an organizational unit and the requirements that an official who will occupy a position in that organizational unit must have. 2) There is a job implementation assessment (employee skills) of each employee who is well maintained and continuously. With this job appraisal, it can be seen about the characteristics, skills, discipline, work performance, and so on of each employee.

The position transformation policy can be traced to refer to various laws and regulations, including Law Number 5 of 2014 concerning State Civil Servants, Government Regulation Number 11 of 2017 concerning Civil Servant Management, Presidential Regulation Number 47 of 2015 concerning the Ministry of PANRB, Presidential Decree 87 of 1999 concerning Functional Position Clusters, Regulation of the Minister of PANRB Number 13 of 2019 concerning Proposal, Determination, and Development of Functional Positions. The most logical reason for this policy is of course the desire to create a more dynamic and professional bureaucracy as an effort to increase effectiveness and efficiency to support the performance of government services to the public. 
The Minister of PANRB is of the view that the position transformation policy can be interpreted as equalizing positions through the appointment of Administrative Officials or in this context echelon 3 and below are transferred to functional positions through adjustments or in passing according to equivalent positions. The criteria for an Administrative Position equivalent to level 3 and below that can be transformed are: 1) Duties and functions of positions related to functional technical services. 2) Duties and functions of positions can be carried out by functional officers. 3) Position based on certain expertise/skills.

However, level 3 and below can still be maintained by the following criteria: 1) Has duties and functions as the Head of a Work Unit with the authority and responsibility for the use of the budget or users of goods/services. 2) Has duties and functions related to the authority/authority, legalization, ratification, document approval, or regional authority. 3) Criteria and other requirements of a specific nature based on the recommendation of each Ministry/Institution to the Minister of PANRB as material for consideration in determining the position required for the position of an Administrative Officer.

\subsection{Human Resource Management}

The human resource management system in practice consists of various types which are determined by the strategies, policies and practices set by the authorities. The strategy in question is an HR strategy that determines the direction for management to take each of its main areas of activity. The policies in question are HR policies which define what management does and provide guidelines that define how specific aspects of HR should be applied and implemented, and HR Practices which consist of management activities involved in managing and developing people and in managing work relationships.

Armstrong [5] in his book (Handbook of Human Resource Management Practice) states that "Human resource management (HRM) is concerned with all aspects of how people are employed and managed in organizations". The aspects referred to by Armstrong [5] are based on the strategy, policies and practices of human resources (human resources strategy, policies and practices) which is a human resource management system which includes: 1) organization, 2) employee resources (people resourcing), 3) learning and development (learning and development), 4) management of rewards (reward management), and 5) employee relations (employee relations).

\subsubsection{Human Resource Planning}

Human resource planning is actually related to the identification of problems, threats and opportunities in the organization and the organizational environment. Meanwhile, according to Nawawi [6], planning is the process of selecting and setting goals, strategies, methods, budgets, and standards (benchmarks) for the success of an activity.

Human Resource Planning (HR) is a series of activities carried out to anticipate future business and environmental demands for the organization and to meet the manpower requirements arising from these conditions [7].

Armstrong [5], in his introduction to human resource planning, states the following: "Human resource planning (HR) ensures that the organization knows and gets the people it needs to carry out current and future business activities". This planning starts from the strategic goals of the organization and analysis of the human resources needed to achieve them. Arrange the plan quantitative and qualitative. This plan forms the basis for the recruitment program and for human resource development plans. 
Furthermore, it is said that the goal of HR planning is to ensure that the organization: 1) Obtain and maintain the quantity and quality of HR required; and 2) Able to anticipate problems that arise from the potential excess or lack of human resources.

According to Manulang [8] human resource planning is a process of providing employees in the quantity and quality required by an organization at the right time in order to get the expected work performance and in an effort to achieve goals. Dale Yoder in Manulang [8] provides an overview of the aspects of human resource planning, as follows: 1) the quantity and quality of human resources; 2) adequate and appropriate human resources; 3) providing an adequate supply of labour, and 4) ensuring the effective use of human resources.

The human resource planning system basically includes the estimation of demand and supply of employees. In detail, the system consists of 4 interrelated and integrated activities: 1) the current supply of human resources, 2) forecasting the supply and demand for human resources, 3) plans to increase the number of individuals who are "qualified", and 4 ) various monitoring and evaluation procedures to provide feedback to the system [7]. 1) Inventory of Human Resources. To assess (skills, abilities/abilities, and their development potential) existing human resources and analyse the use of current personnel; 2) Human Resources Forecast. To predict the demand and supply of employees in the future (both quantity/quantity and quality); 3) Preparation of Human Resource Plans. To integrate demand and supply of personnel in the acquisition of a 'qualified' workforce through recruitment, selection, training, placement, transfer, promotion and development; and 4) Monitoring and Evaluation. To provide feedback to the system and monitor the degree of achievement of the goals and objectives of human resource planning.

\subsubsection{Human Resources Development}

Human resource development is a process for the development and smoothening of human expertise through the development and training of organizational personnel and this development is aimed at improving organizational performance.

According to Samsudin increasing the efficiency and productivity of human resources can be achieved by increasing: 1) Employee knowledge; 2) Employee skills; and 3) Attitudes and responsibilities of employees towards their duties. According to McLean \& McLean, Human Resource Development is any activity and process, including initially through longterm goals, has the potential to be developed again. It is based on knowledge, expertise, productivity and satisfaction. Chalofsky and Lincoln state that the discipline of human resource development is a study of how individuals and groups in organizations experience change through learning.

There are several methods of developing human resources that can be selected, namely: 1) Training Methods. The definition of training (training) is intended to improve the mastery of various skills and techniques for mastery of certain skills and work implementation techniques, in detail and routinely.

According to Murti and Soeprihanto [9], there are two training methods: 1) Training. Training is an activity to improve the ability of an employee by increasing the abilities and skills of employees; 2) Education (education). Education is an exercise to improve an employee's training in general knowledge and economic knowledge in general, including an increase in theoretical mastery and decision-making skills in dealing with organizational problems in the company.

There are three main categories of development, namely: 1) Coaching. Cho acing is a form of development carried out in a company by superiors by guiding officers to do work in 
an informal and usually unplanned manner, for example how to do work, how to solve problems. 2) Job Rotation. Job Rotation is a formally planned program by assigning employees to several different jobs in different parts of the organization to increase knowledge about work in the organization. 3) Apprenticeship (Apprenticeship) Apprenticeship is training that combines classroom lessons with practice in the field, where after a number of theories are given to participants, participants are brought to practice in the field.

\subsubsection{Compensation (Rewards)}

Compensation is a fee. It is a cost incurred by the organization/company to its members/employees from the performance it produces. The company or agency expects that this paid compensation earns greater work performance benefits from the employee. So the value of employee work performance must be greater than the compensation paid by the company or agency so that the company or organization gets a profit and the continuity of the agency company is guaranteed.

According to Hasibuan [10] compensation is all income in the form of money or goods directly or indirectly received by employees in return for services provided to the company, while according to Wether and Davis in [10] that compensation is what a worker receives as reply from the work he received. Either hourly wages or periodic wages are designed and managed by the Personnel Department.

Compensation can be divided into two major groups, namely the direct compensation group, which consists of benefits received directly, routinely or periodically by workers or employees and indirect compensation which consist of benefits received irregularly or periodically, which are received later or when something happens to the employee.

\subsection{Functional Positions}

Functional positions (knowledge workers) are high-level workers who apply theoretical and analytical knowledge in product and service development [11]. This functional position plays a very important role. in organizations and employment today Amar and Hlupic [12], Shujahat et al. [13] both in the world in general and in Indonesia in particular. Functional positions are used as the basis for maintaining an organization's competitive advantage through intellectual capabilities [11].

In this 20th century, the role of functional positions has become very important considering that in this era people who work with information are needed and who are able to develop and use knowledge in the workplace [14][15]. In reality, there is a relationship between human resource architecture and functional positions, namely that functional positions are in accordance with commitment-based human resource architectures that require core knowledge and are incompatible with human resource architectures based on collaborative, compliance and productivity [16].

A functional position is one of the types of civil service positions in addition to highranking positions and administrative positions as stated in Law Number 5 of 2014 concerning State Civil Apparatus (ASN Law). In Article 1 of the ASN Law it is stated that what is meant by a functional position is a functional position is a group of positions containing functions and tasks related to functional services based on certain expertise and skills, while the definition of a functional official is an ASN employee who holds a Functional Position in a government agency. 
In further regulation, both in Government Regulation Number 11 of 2017 concerning Management of Civil Servants and in Regulation of the Minister of State Apparatus Empowerment number 13 of 2019 concerning Proposal, Determination and Development of Functional Positions, it is explained about 2 (two) functional position groups, namely functional positions of expertise and job functional skills. Expertise Functional Position is a professional qualification functional position with tasks based on mastery of science and technology in the field of expertise based on the relevant scientific discipline and/or based on certification equivalent to expertise and determined based on certain accreditation and requires minimum educational qualifications of undergraduate or diploma IV. Skills Functional Position is a functional position of technician or professional support whose duties and functions are carried out using certain work procedures and techniques and is based on the control of technical knowledge in one or more scientific fields based on a specified certification and only requires a diploma III educational qualification. The two groups of functional positions each consist of main expert, intermediate expert, junior expert and first expert for expertise functional positions and supervisors, advanced, skilled and beginners for skills positions.

Furthermore, based on Government Regulation Number 17 of 2020 as an amendment to Government Regulation Number 11 of 2017, it is stated that Functional Officials are located below and are directly responsible to middle high-ranking officials, high-ranking pratama officials, administrator officials, or supervisory officials who are related to implementation the job of JF. Determination of position and responsibility is directly adjusted to the organizational structure of each government agency.

Thus, a functional position can be concluded as the position of the state civil apparatus which is not explicitly in the organizational structure with the main function of carrying out the functions of the organization and is based on certain expertise or skills. Although functional positions are not explicitly listed in the organizational structure of the government bureaucracy, from the point of view of their functions, these positions must still exist to enable the organization to carry out its main duties. Appointments of functional positions are intended as a means of professional development and career development for civil servants. In addition, to achieve development goals, it is necessary to appoint functional officials who need to be properly fostered by using a career system and work performance system in order to create an effective and efficient government organization.

Currently there are 222 types of certain functional positions with 25 clumps of positions which are stipulated by the Regulation of the Ministry of Administrative Reform and Bureaucratic Reform. These functional positions are grouped into a functional group, namely a group of functional positions which have duties and functions that are closely related to one another in carrying out one of the general duties of the government.

Each functional group of positions has a supervisory agency that is tasked with providing guidance to achieve work optimization, for example the Policy Analyst Functional Position under the supervisory agency of the State Administration Institute

\subsection{Policy Analyst}

According to Friedrich [17] policy is a decision proposed by an individual, group or government that aims to solve a problem. In addition, Lester [18] define policy as a process or series of government activities to solve public problems.

Analysis is an investigation of an event (essays, actions, etc.) to find out the true situation (causes, issues, and so on), or it can be interpreted as an elaboration of a subject on its various 
parts and an examination of the parts themselves and the relationship between the parts for obtain the correct understanding and understanding of the overall meaning (Big Indonesian Dictionary). Based on Keraf [19], analysis is a process to break something into parts that are interrelated with one another.

Policy analysis is the process or activity of synthesizing information, including research results, to produce recommendations for public policy design options [20]. Dunn [21] argues that policy analysis is an applied social science discipline that uses a variety of research methods and arguments to generate and transfer information relevant to policy, so that it can be used at the political level in order to solve policy problems.

Simatupang [22] formulates the basic concept characteristics of policy analysts into 5 (five) characteristics, so that it can be seen that policy analysis is different from policy research, namely:

First, policy analysis is a process or activity of "synthesizing" information which means the integration of various information, including research results, so that a consistent conclusion can be obtained. This means that the object of policy analysis is the formulation process and policy package. The main activity of policy analysis is the systematic gathering of information and drawing logical conclusions from it. Thus, policy analysis is based on scientific principles.

Second, one of the main sources of information that becomes the material for policy analysis is research results. This means that policy analysis is a further processing process of research results so that they are ready to be used in decision making and public policy design. Therefore, policy analysis is a form of dissemination of research results.

Third, the output of policy analysis is a recommendation on decision options or public policy design. This means that the output of the policy is in the form of advice or operational guidance on materials for making public decisions for specific clients. Therefore, policy analysis must be presented in a clear, concise, concise, complete and thorough manner.

Fourth, policy analysis clients are public policy decision makers (government and DPR) and interest groups on government policies. Client policy analysis users are specific. This is directly related to the output of policy analysis in the form of advice on public policy.

Fifth, client-oriented policy analysis. This is an implication of the nature of policy analysis which produces ready-to-use decision advice for specific clients. Without clientoriented policy analysis is unlikely to be ready to use. This means that policy analysis must be based on "from, by and for clients". Policy analysis is only conducted when there is a demand or "predictably" that the client really needs. Policy analysis is driven by the immediate needs of its clients (client's need push).

Policy Analysts are Civil Servants who are given the task, responsibility, and authority to carry out policy studies and analysis within the Central and Regional agencies (Permenpan RB Number 45 Year). According to Weimer and Vining [23], a policy analyst must have the following capability requirements:

a. Able to collect, organize and communicate information under a very tight schedule and access to related parties is very limited. For this reason, policy analysts must have long enough work experience and extensive associations.

b. Have the vision and ability to formulate public problems in a realistic context. For this reason, policy analysis must have extensive knowledge and visionary thinking.

Have technical skills that enable it to predict and evaluate the impact of policy options more precisely and with greater confidence. For this reason, policy analysts must master economic, political, statistical and technical science in related aspects. 


\section{Method}

\subsection{Research Approach}

The approach of this research is descriptive and the study is conducted qualitatively. The reason for using qualitative research, considering the problems that arise in human resource management will be accurate with a qualitative approach. Research aims to describe systematically the facts or characteristics of a particular field factually and accurately.

The descriptive qualitative approach in this research tends to be a case study method. The case study method is a method of researching the problem descriptively.

The research was conducted intensively, in detail and in depth concerning human resource management in the functional positions of policy analysts at the Ministry of Administrative Reform and Bureaucratic Reform.

\subsection{Research Phenomena}

The focus of the research carried out is on the 5 (five) elements of a human resource management system associated with a policy analyst functional position, which includes: organization, people resourcing, learning and development (learning and development). development), management of rewards (reward management) and employee relations (employee relations), which then made questions as a basis for literature review guidelines regarding civil servant human resource management [5]. These literature review guidelines are aimed at: 1. Knowing the HR management functional position of a policy analyst; 2 . Analyzing the system of organizing (organization) functional positions of policy analysts (rank and position and career pattern); 3. Analyzing the recruitment system for policy analyst administrators (people resourcing), which includes preparation and determination of needs and procurement; 4. Analyzing the learning and development system of policy analysts (learning and development) which includes career development, promotions, transfers, and performance appraisals, and analyzing the reward management system for functional policy analyst positions which include: payroll and allowances, awards, pension and old age benefits; and 5. To analyze the relationship between employees (employee relations) which includes: discipline and dismissal.

This research is an applied research. The study of field research data will be presented editorial and describe the categories related to the topic in this research. Therefore, the focus of the research in this study in terms of the objective of descriptive explanations.

\subsection{Data Validity}

The data is trusted because it is obtained from parties directly related to the research topic, in this case, who know human resource management in the functional positions of policy analysts. Determination of the validity (trustworthiness) of examination technique data through four criteria used, credibility, transferability, dependability and confirm ability.

\subsection{Data Source Selection Technique and Data Source}

This study is to obtain information about human resource management in policy analyst functional positions obtained from data sources in the form of documents, literature and related legislation. The selection of data sources in qualitative research is not meant to make 
generalizations. The concept of sampling in qualitative research is concerned with selecting key data sources that can provide reliable information. In this process, the snowball technique is applied, where the number of data sources is determined by the completeness of the data collected.

Researchers determine the source of the data in this study by using a snowball technique with certain criteria that are in accordance with the problem and research objectives. The data source criteria selected in this study are documents, literature and laws and regulations that discuss human resource management in policy analyst functional positions.

\subsection{Data Collection Technique}

The data in this study consisted of primary data and secondary data. Primary data is data obtained through literature study. Literature review is the process of collecting data by using information from data sources in the form of documents, literature, reports, publications, and regulations related to the aspects studied.

In order to obtain data that is as accurate as possible, researchers use triangulation techniques with data sources from related agencies, such as the State Administration Institute as a supervisor for policy analyst functional positions and policy analyst professional organizations. Secondary data includes research results and articles in journals or study results related to research focus and locus including regulations relating to the management of positions in general and regulations related to the management of policy analyst functional positions, such as those in the Ministry of Administrative and Bureaucratic Reform, State Administration Institution, State Civil Service Agency, and Indonesian Policy Analyst Association.

\subsection{Data Processing and Analysis Techniques}

Data processing and data analysis in qualitative research are separate activities. This can be seen in the stages of qualitative data analysis, namely: data reduction, data presentation and conclusion/verification [24]. Data reduction is defined as the process of selecting, focusing on simplifying, abstracting and transporting raw data that emerge from written records in the field. The data reduction step can actually be categorized as data processing.

However, if the conclusions put forward at an early stage are supported by valid and consistent evidence when the researcher returns to the field to collect data, then the conclusions put forward are credible conclusions. Thus, this study uses triangulation techniques to determine the validity of the data used in this research.

The data analysis activities of this research began with field data collection. The results of the data collection then reduce the data by sorting it into certain concept units, certain categories and certain themes. Furthermore, data is presented in certain forms such as sketches, synopses, matrices or other forms. This is necessary to facilitate the presentation and confirmation of conclusions.

\section{Results and Discussion}

The Strategic Steps of Bureaucratic Simplification at the Ministry of Administrative and Bureaucratic Reform as the object of research in the context of transferring administrator positions to functional positions are as follows: 
1) Identifying Echelon III and Echelon IV work units that can be simplified and shifted their structural positions according to the job map starting October 2019.

2) Mapping the positions and structural officers of Echelon III and Echelon IV in work units affected by the transition and at the same time identifying the equivalence of these positions with functional positions that will be occupied in October 2019.

3) Mapping functional positions that can and are needed to accommodate the transition of Echelon III and Echelon IV structural officials who were affected by cuts as a result of the bureaucratic simplification policy in October 2019.

4) Aligning budget requirements related to income in positions affected by the November 2020 bureaucratic simplification policy.

5) Carry out socialization and provide understanding to all employees regarding the policy of simplifying the bureaucracy, so that each employee can adjust to a dynamic, agile and professional organizational structure in order to improve organizational performance and public services in November 2019.

6) Submission of simplification activity proposals to the Minister of Administrative and Bureaucratic Reform in the form of softcopy in December 2019.

7) Determination of the Organizational Structure and Work Procedure of the Minister of Administrative and Bureaucratic Reform which is the result of simplifying the bureaucracy in December 2020.

8. The process of transforming Echelon III, Echelon IV, and Echelon V structural positions into functional positions is carried out based on the mapping results in January 2020.

9) Carry out a transfer of positions in a professional manner, free from corruption, and without conflicts of interest while still applying the principle of prudence, in line with good governance, and guided by the provisions of the legislation in February 2020.

10) Carry out follow-up of personnel administration documents in the transfer of structural positions Echelon III and Echelon IV to further functional positions in the Regulation of the Minister for Administrative Reform and Bureaucratic Reform through the appointment of in passing/adjustments to functional positions specifically in February 2020.

Facts on the Transfer of Administrative Position into a Policy Analysis Functional Position at the Ministry of Administrative and Bureaucratic Reform are as follows:

1) The position of a policy analyst functional position that is not yet in accordance with the policy analyst position;

2) Additional duties as coordinator and sub-coordinator which add to the workload of the policy analyst functional position but do not count as job performance;

3) There are several policy analyst functional officers who do not meet the requirements of the position so that it is necessary to carry out certain policies such as competency tests and opportunities within 3 years to qualify for education;

4) Career patterns that are not clearly organized because the transfer of positions does not take into account the job map;

5) There is confusion from functional officials regarding the collection of credit numbers as a condition for promotion and rank;

6) Relatively decreased income by one hundred thousand rupiah.

Model of Transfer of Administrative Position into a Policy Analysis Functional Position is illustrated in the following figure: 


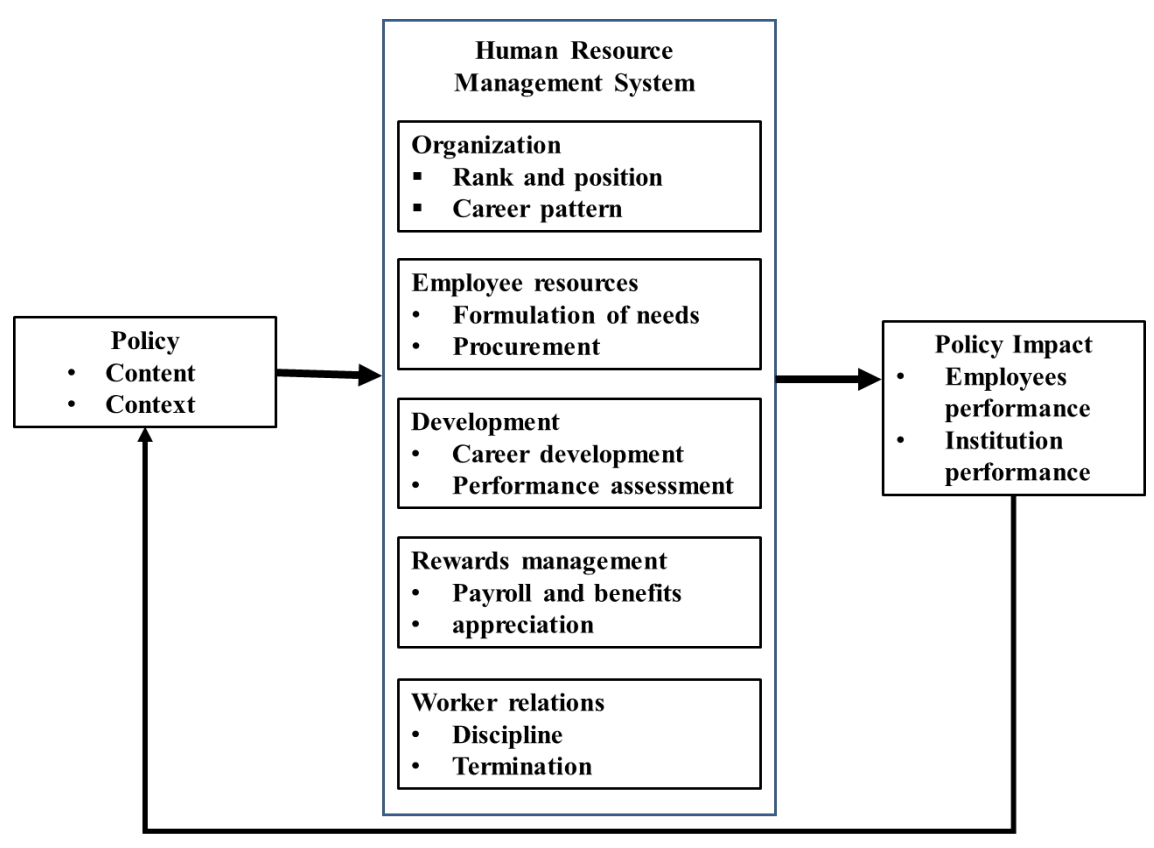

Fig. 1. Model of Transfer of Administrative Position into a Policy Analysis Functional Position

The research was conducted using qualitative methods and using primary data obtained through literature studies. Limitations in this study include the subjectivity of researchers. This study relies heavily on the researchers' interpretation of the implied meanings of the literature review so that a tendency to bias remains. To reduce bias, a triangulation process is carried out, namely triangulation of sources and methods. Source triangulation was done by cross checking the data with facts from different data sources and from other research results. While the method triangulation was carried out using several methods in the literature review

\section{Conclusion}

The transfer of an administrative position to a functional one needs to pay attention to human resource factors which include organization, resources, development, reward management and employee relations which will have an impact on the performance of employees and institutions.

In-depth study and the use of a pilot project are required to obtain a model for transferring administrative positions to functional positions so as not to cause problems that are detrimental to employees and the organization.

It is recommended that the implementation of the transfer of administrative positions to functional ones requires good planning and preconditions given that the impact has a large scale and long term. 


\section{References}

[1] D. Damanhuri and R. Jawandi, "Reaktualisasi reformasi birokrasi menuju good governance," in Prosiding Seminar Nasional Pendidikan FKIP, 2017, vol. 1, no. 2.

[2] M. Thoha, "Birokrasi Pemerintah di Era Reformasi," Jakarta. Kencana, 2008.

[3] P. Y. Kwo et al., "Glecaprevir and pibrentasvir yield high response rates in patients with HCV genotype 1-6 without cirrhosis," J. Hepatol., vol. 67, no. 2, pp. 263-271, 2017.

[4] H. Logeman, The English Faust-book of 1592, vol. 24. H. Engelcke, 1900.

[5] M. Armstrong and S. Taylor, Armstrong's Handbook of Human Resource Management Practice: Edition 13. Kogan Page, 2014.

[6] H. H. Nawawi, "Manajemen Sumber Daya Manusia untuk bisnis yang kompetitif," 2018.

[7] T. H. Handoko, "Manajemen personalia dan sumber daya manusia. Yogyakarta." BPFE Press, 2012.

[8] M. Manulang and D. Manajemen, "Ghalia Indonesia," Jakarta Timur, 1982.

[9] M. Sumarni and J. Soeprihanto, "Pengantar Bisnis," Yogyakarta Lib., 1998.

[10] M. S. Hasibuan, Organisasi dan Motivasi. Jakarta: Bumi Aksara, 2012.

[11] A. W. Issahaka and R. Lines, "Research literature on leadership of knowledge workers: where are we, and where should we be heading?," J. Intellect. Cap., 2020.

[12] A. D. Amar and V. Hlupic, "Leadership for knowledge organizations," Eur. J. Innov. Manag., 2016.

[13] M. Shujahat, M. J. Sousa, S. Hussain, F. Nawaz, M. Wang, and M. Umer, "Translating the impact of knowledge management processes into knowledge-based innovation: The neglected and mediating role of knowledge-worker productivity," J. Bus. Res., vol. 94, pp. 442-450, 2019.

[14] D. H. Pink and D. H. Pink, A whole new mind: Moving from the information age to the conceptual age, vol. 50. Riverhead Books New York, 2005.

[15] E. Matusov and P. Sullivan, "Pedagogical violence," Integr. Psychol. Behav. Sci., vol. 54, no. 2, pp. 438-464, 2020.

[16] L. Gaižauskienè and Ž. Tunčikienè, "The concept and role of knowledge worker and workplace fit in learning organisation," Int. J. Learn. Chang., vol. 8, no. 3-4, pp. 245-260, 2016.

[17] C. J. Friedrich, "Public policy and the nature of administrative responsibility," Public, pp. 3-24, 1940.

[18] J. Stewart Jr, D. Hedge, and J. P. Lester, Public policy: An evolutionary approach. Nelson Education, 2007.

[19] G. Keraf, Komposisi: sebuah pengantar kemahiran bahasa. Nusa Indah, 1993.

[20] W. Williams, Social Policy Research and Analysis. American Elswier Publishing Company. 1971.

[21] W. Dunn, "Public policy analysis: An introduction. 2004." New Jersey, Pearson Prentice Hall.

[22] P. Simatupang, "Analisis Kebijakan: Konsep dasar dan prosedur pelaksanaan," Anal. Kebijak. Pertan., vol. 1, no. 1, pp. 1-23, 2017.

[23] D. L. Weimer and A. R. Vining, Policy analysis: Concepts and practice. Taylor \& Francis, 2017.

[24] M. B. Miles and A. M. Huberman, “Analisis Data Kualitatif. Terjemahan Tjetjep Rohendi Rohidi,” Jakarta Penerbit Univ. Indones., 1992. 